\title{
The Factors Affecting Financial Reporting Reliability: An Empirical Research of Public Listed Companies in Thailand
}

\author{
Nattawut Tontiset, Sirilak Kaiwinit \\ Mahasarakham University, Mahasarakham, Thailand
}

\begin{abstract}
The objective of this research is to examine the antecedents of financial reporting reliability of Thai-listed companies. Accountant professional ethics, accounting information system (AIS) quality, audit committee effectiveness, and audit firm quality are assumed to be the antecedents of financial reporting reliability. The listed companies in the Stock Exchange of Thailand (SET) are samples of the research. A mail survey procedure via the questionnaire was used for data collection from chief accountant officer. The overall results indicate that accountant professional ethics, AIS quality, audit committee effectiveness, and audit firm quality have a positive significant effect on financial reporting reliability. The results reveal that firms should develop accountant professional ethics, AIS quality, audit committee effectiveness, and audit firm quality in order to build reliable financial reporting. Overall, the results of this research contribute to chief accounting officers, accounting practitioners, and firms to emphasize development and support the generation of financial reporting reliability for financial reporting users.

Keywords: financial reporting reliability, accountant professional ethics, AIS quality, audit committee effectiveness, audit firm quality
\end{abstract}

\section{Introduction}

The primary objective of accounting is to provide information that is useful for decision makers, both external and internal parties (Ogundana, Ojeka, Ojua, \& Nwaze, 2017; Mbobo \& Ekpo, 2016; Berger, 2011). The prior accounting research also found that accounting information provides useful information for decision makers, such as investor, creditor, suppliers, regulatory manager, owner, employee, and others (Socea, 2012; Beyer, Cohen, Lys, \& Walther, 2010; Biddle, Hilary, \& Verdi, 2009; Baker \& Barbu, 2007; Marriner \& Nuseiben, 2004). Furthermore, contemporary financial accounting research also investigated the information content of earnings, earnings reflecting factors that affect stock price, and earnings announcement (Meek \& Thomas, 2004; Beaver, 1998; Watts \& Zimmerman, 1986).

Last century, financial accounting research also investigated the value relevance of accounting numbers, such as book value, earnings per share, intangible asset, and cash flow (Baker \& Barbu, 2007; Cheng, Ferris, Hsieh, \& Su, 2005). Most of the results found that accounting numbers provide useful information for investors and decision makers (Socea, 2012; Beyer et al., 2010; Biddle et al., 2009; Meek \& Thomas, 2004). Thus, the objective of financial reporting is to provide information about the reporting entity that is useful to existing and

Nattawut Tontiset, Ph.D. (Accounting), Assistant Professor of Accounting and Director of Bachelor Program in Accountancy, Mahasarakham Business School, Mahasarakham University. Email: Nattawut.t@acc.msu.ac.th.

Sirilak Kaiwinit, Lecturer and Researcher of Business Computer Department, Mahasarakham Business School, Mahasarakham University. 
potential financial users in making decisions about the entity (Tontiset, 2018a; McCartney, 2004; Marriner \& Nuseiben, 2004). Moreover, financial reporting reliability is very important for decision makers (Socea, 2012; Maines \& Wahlen, 2006).

From the perspective of financial accounting research, the research found that there has been little empirical evidence of antecedents of financial reporting reliability (Berger, 2011; Beyer et al., 2010; Naser \& Nuseibeh, 2003). Moreover, the key characteristics of financial reporting reliability are neither clear nor covered to explain the phenomenon of qualitative characteristics of financial reporting (Yurisandi \& Puspitasari, 2015; Berger, 2011; Biddle et al., 2009). Thus, this research aims to investigate the antecedents of financial reporting reliability of the listed companies in the SET.

The key research question of this research is: "Do accountant professional ethics, AIS quality, audit committee effectiveness, and audit firm quality have an influence on financial reporting reliability?”. Therefore, the main objective of this research is to investigate the effects of accountant professional ethics, AIS quality, audit committee effectiveness, and audit firm quality on financial reporting reliability.

This research generates both theoretical and managerial contributions. For the theoretical contribution, this research provides an important extension on previous knowledge and relevant literature of financial reporting reliability. This research applies the resource-based view (RBV) of the firm to explain internal resources and capabilities including accountant professional ethics, AIS quality, and audit committee effectiveness which can affect financial reporting reliability. Furthermore, stakeholder theory to explain the firms must be providing external auditor in order for financial reporting reliability to generate contributions of accounting information to stakeholders. For managerial contribution, the findings of this research provide information for chief accountant officers and managers to identify and justify the key component of financial reporting reliability in order to gain firm sustainability.

The remainder of this paper is organized as follows. The next part provides theoretical foundation. The third section provides a brief literature review and links to hypothesis development. The fourth section provides research methods including sample and data collection procedure, the variable measurements of each construct, the instrument verification, the statistics, and equations to test the hypotheses are provided. The fifth section provides the results and discussion. The sixth section provides both theoretical and managerial implications. The seventh section provides limitations and suggestions for future research. The last section provides the conclusion.

\section{Theoretical Foundation and Research Model}

\section{RBV: Internal Resource and Capability}

The RBV of the firm refers to bundles of resources heterogeneously distributed across firms and that resource differences persist over time (Russo \& Fouts, 1997; Barney, 1991). Internal resources include various elements that can be used to implement value-creating strategies, such as specific physical assets, intangible assets, human resources, effective organizational system, and other competencies (Henri, 2006). With regard to the RBV, firms attempt to exploit valuable, heterogeneous, rare, and inimitable resources to develop and sustain competitive advantages (Russo \& Fouts, 1997; Henri, 2006). For this research, we employ the RBV to explain internal resources and capabilities including accountant professional ethics, AIS quality, and audit committee effectiveness which are set as the antecedents of financial reporting reliability in research model. 


\section{Stakeholder Theory}

For this research, we also employ stakeholder theory to explain the phenomenon of the relationships between audit firm quality and financial reporting reliability. Corresponding to stakeholder theory implies that an outside group is involved with the corporation both direct and indirect interaction, for example, investor, ownership, customer, employee, government, and bonding (Beaver, 1998; Lehman, 1999). The corporation in the stock exchange also focuses on the need to control stakeholders who are deemed to have a more direct and critical impact on companies (Mahadeo, Oogarah-Hanuman, \& Soobaroyen, 2011). Thus, most of the companies in the SET must provide big audit firm in order to give financial reporting users confidence. Overall, this research has developed the research model and hypotheses as shown in Figure 1 which builds on both RBV of the firm and stakeholder theory as follows.

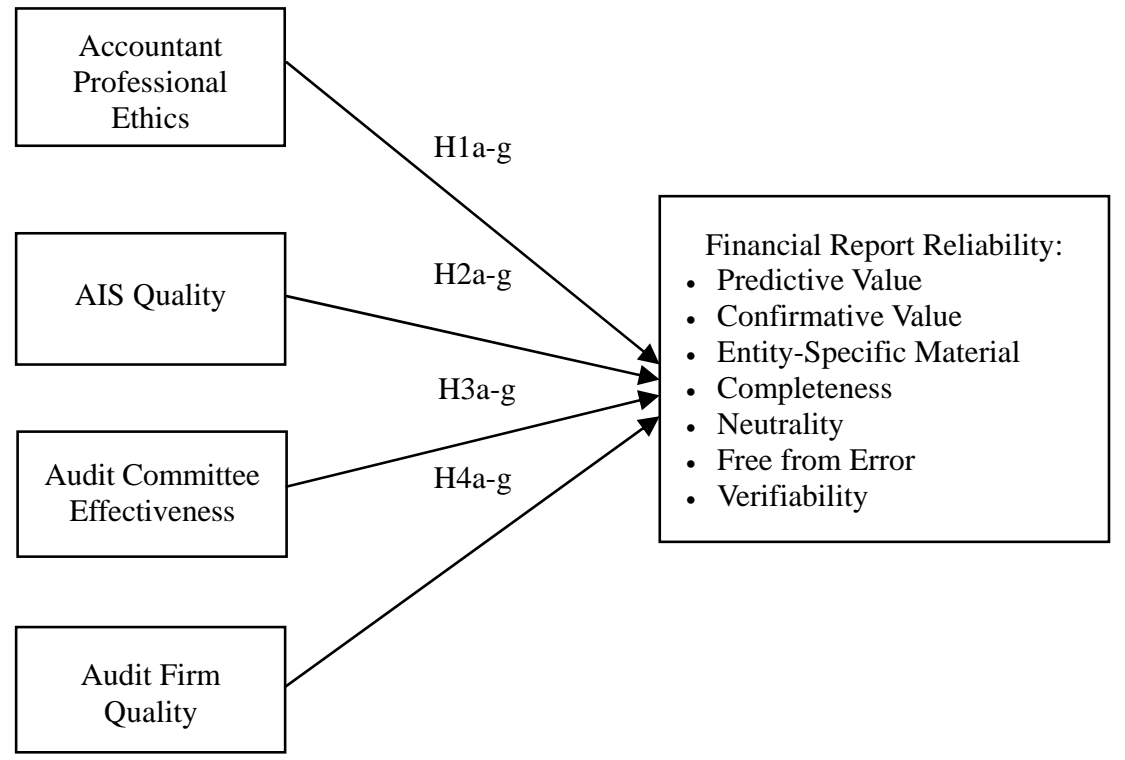

Figure 1. Research model of the antecedents of financial reporting reliability.

\section{Literature Review and Hypothesis Development}

\section{Financial Reporting Reliability}

The basic objective of financial reporting is concerned with providing useful information for economic decision-making. Financial reporting reliability is defined as the published financial statements that are being prepared reliably in order to provide information useful to users in making economic decisions (Tontiset \& Kaiwinit, 2015; Socea, 2012; Shahwan, 2008; Marriner \& Nuseiben, 2004). For this research, we focus on financial reporting reliability in seven dimensions that are based on the qualitative characteristics of financial statement in conceptual framework for financial reporting including predictive value, confirmative value, entity-specific material, completeness, neutrality, free from error, and verifiability (Ogundana et al., 2017; International Accounting Standards Board [IASB], 2015; Yurisandi \& Puspitasari, 2015; Hasan, Abdullah, \& Hossain, 2014). Biddle et al. (2009) suggested that higher-quality financial reporting should increase investment efficiency. Hence, the hypotheses are proposed as follows. 


\section{Accountant Professional Ethics and Financial Reporting Reliability}

Accountant professional ethics refers to an accountant's behavior that corresponds with the code of professional ethics of the International Federation of Accountants (IFAC) in order to help predict competent outcome in a certain job that encompasses abilities, knowledge, skills, experience, and technology competency (Tontiset, 2018b; Enofe, Ukpebor, \& Ogbomo, 2015; Flood \& Wilson, 2008; Kennedy \& Dresser, 2005). Prior researches indicated that professional ethics has a significant impact on financial reporting reliability (Adediran, Alade, \& Oshode, 2013; Flood \& Wilson, 2008). Thus, the hypothesis is proposed as follows:

Hypothesis 1: The higher the accountant professional ethics is, the more likely that the firms will gain greater financial reporting reliability: (a) predictive value; (b) confirmative value; (c) entity-specific material; (d) completeness; (e) neutrality; (f) free from error; and (g) verifiability.

\section{AIS Quality and Financial Reporting Reliability}

AIS quality refers to the latency of accounting information system that provides building accounting information and financial reporting reliability. The characteristics of AIS quality are producing accurate data, timeliness, update, and effective link to other systems (Altamuro \& Beattey, 2010; Peppard \& Ward, 2004; O’Donnell \& David, 2000; Murthy \& Swanson, 1992). Prior researches indicated that AIS quality has a significant impact on financial reporting reliability (Abdullah, Almsafir, \& Al-Smadi, 2015; Altamuro \& Beattey, 2010; Peppard \& Ward, 2004; O’Donnell \& David, 2000). Thus, the hypothesis is proposed as follows:

Hypothesis 2: The higher the AIS quality is, the more likely that the firms will gain greater financial reporting reliability: (a) predictive value; (b) confirmative value; (c) entity-specific material; (d) completeness; (e) neutrality; (f) free from error; and (g) verifiability.

\section{Audit Committee Effectiveness and Financial Reporting Reliability}

Audit committee effectiveness refers to that audit committee team has strong abilities, knowledge, and experience in both corporate governance and the Committee of Sponsoring Organizations of the Treadway Commission (COSO) that can enhance financial reporting quality (Tontiset \& Kaiwinit, 2015; Johnson, Lowensohn, \& Reck, 2012; Kennedy \& Dresser, 2005). Corporate governance plays an important role in enhancing the financial reporting process (Suttipun, 2018; Cohen, Krishnamoorthy, \& Wright, 2004). J. Ma and C. Ma (2011) and Moeller (2011) concluded that the basis of COSO framework consists of five dimensions including the control environment, risk assessment, control activity, information and communication, and monitoring. Prior accounting research revealed that audit committee effectiveness is associated with financial reporting reliability (Asiriuwa, Aronmwan, U. Uwuigbe, \& O. R. Uwuigbe, 2018; Kamolsakulchai, 2015; Klai, 2011; Schneider, Gramling, Hermanson, \& Ye, 2009; Ashbaugh-Skaife, Collins, \& Kinney, 2007). Hasan et al. (2014), Spatacean (2012), and Jokipii (2010) suggested that audit committee effectiveness is providing reasonable assurance regarding the reliability of financial reporting. Moreover, Kusnadi, Leong, Suwardy, and Wang (2015) and Li and Shroff (2014) recommended that incremental independence of audit committees enhances financial reporting quality because audit committees already consist of a majority of independent directors. Thus, the hypothesis is proposed as follows:

Hypothesis 3: The higher the audit committee effectiveness is, the more likely that the firms will gain greater financial reporting reliability: (a) predictive value; (b) confirmative value; (c) entity-specific material; (d) completeness; (e) neutrality; (f) free from error; and (g) verifiability. 


\section{Audit Firm Quality and Financial Reporting Reliability}

Audit firm quality is defined as an audit firm that focuses on quality-control procedures in order to maintain strictly high standards by following Generally Accepted Auditing Standards (GAAS) (Tontiset \& Ittarat, 2014; Wooten, 2003). For this research, we identify audit quality as consisting of five dimensions including industry expertise, client experience, audit manager involvement, audit committee involvement, and skepticism (Samelson, Lowensohn, \& Johnson, 2006; Francis, 2004; Wooten, 2003; Behn, Carcello, Hermanson, \& Hermanson, 1997; Sutton, 1993; Carcello, Hermanson, \& McGrath, 1992). Audit firm quality is higher concentration of client's industry expertise, client experience, audit manager involvement, audit committee involvement, and skepticism which will have higher financial reporting quality and reliability (Tepalagul \& Lin, 2015; Kamolsakulchai, 2015; Behn et al., 1997; Carcello et al., 1992). Thus, the hypothesis is proposed as follows:

Hypothesis 4: The higher the audit firm quality is, the more likely that the firms will gain greater financial reporting reliability: (a) predictive value; (b) confirmative value; (c) entity-specific material; (d) completeness; (e) neutrality; (f) free from error; and (g) verifiability.

\section{Research Methods}

\section{Sample and Data Collection Procedure}

Sample of this research is the companies in the SET. The main reason to choose them for investigation is that they are large firms with hierarchical structure, a lot of authorized capital, and process standardization (Pavabutr \& Prangwattananon, 2009). Accounting controllers or chief accountant officers are chosen as key participants because they have a direct effect on financial reporting practices in each corporation. Moreover, they are well suited to provide the details of accounting information and other organizational information needed for the tests (Cadez \& Guilding, 2008). SET database ${ }^{1}$ is used for identifying a number of business and companies' addresses. A mail survey procedure via the questionnaire was used for data collection and when completed, each was returned by the respondents directly to the researchers to ensure confidentiality.

All 580 listed companies in the SET were selected as the sample size. With regard to the questionnaire mailing, 22 questionnaires were undeliverable because some firms were no longer in business or had moved to unknown locations. Deducting the undeliverable questionnaires from the list of database, the valid mailing was 558 questionnaires, from which 130 responses were received. The questionnaires were completed and returned, and only 119 were usable. Therefore, the effective response rate was approximately 21.32\%.

\section{Questionnaire Development and Variable Measurement}

Questionnaire development. In this research, a questionnaire consists of five parts. Part one asks for personal information. Part two is for general information of listed companies in the SET. Parts three and four are related to evaluating each of the constructs in the research model designed by a 5-point Likert scale, ranging from 1 (strongly disagree) to 5 (strongly agree). Part three is the measurement of financial reporting reliability including predictive value, confirmative value, entity-specific material, completeness, neutrality, free from error, and verifiability. Part four is the measurement of the antecedents of financial reporting reliability including accountant professional ethics, AIS quality, audit committee effectiveness, and audit firm quality. Finally, an open-ended question for suggestions and opinions of chief accountant officers is included in part five.

\footnotetext{
${ }^{1}$ As of December 2017, retrieved from https://www.set.or.th.
} 
Variable measurement. The measurement development procedures involve the multiple items development for measuring each construct in the conceptual model. All constructs are the abstractions that cannot be directly measured or observed and should be measured by multiple items (Churchill, 1979). To measure each construct in the research model, all of variables are gained from the survey and are measured by a 5-point Likert scale, ranging from 1 (strongly disagree) to 5 (strongly agree).

Dependent variable. Financial reporting reliability refers to the published financial statements that are being prepared reliably in order to provide useful information to users in making economic decisions (Tontiset \& Kaiwinit, 2015; Socea, 2012; Shahwan, 2008). Moreover, financial reporting reliability implies that accounting information can be measured using the appropriate method which is based on Generally Accepted Accounting Principles (GAAP), i.e., International Financial Reporting Standards (IFRS) (Socea, 2012; Berger, 2011). Financial reporting reliability provided information useful to users in making economic decisions (Mbobo \& Ekpo, 2016; IFAC, 2012; Socea, 2012; Berger, 2011; Shahwan, 2008).

This variable is measured using seven characteristics of qualitative financial reporting which are based on the qualitative characteristics of financial reporting including predictive value, confirmative value, entity-specific material, completeness, neutrality, free from error, and verifiability (Ogundana et al., 2017; IASB, 2010; 2015; Yurisandi \& Puspitasari, 2015; Hasan et al., 2014; IFAC, 2012; Socea, 2012; Shahwan, 2008). This attribute shows both relevance and faithful representations of qualitative characteristics of financial statement. The measurement of each attribute depends on literature review that is also detailed.

Predictive value refers to that the information in financial statement must be used as an input to process employed by users to predict future outcomes (Ogundana et al., 2017; Yurisandi \& Puspitasari, 2015; IASB, 2015). Moreover, financial information with predictive value is employed by users in making prediction. Predictive value is measured using three-item scale modified from Ogundana et al. (2017), Yurisandi and Puspitasari (2015), and Hasan et al. (2014).

Confirmative value refers to that the information in financial statement must provide feedback data about (confirms or change) previous evaluations (Ogundana et al., 2017; IASB, 2015). Confirmative value is measured using three-item scale modified from Ogundana et al. (2017) and Yurisandi and Puspitasari (2015).

Entity-specific material refers to the information that is based on the nature or magnitude, or both, of the items to which the data relate in the context of an individual entity's financial report (Ogundana et al., 2017; IASB, 2015). Entity-specific material is measured using three-item scale modified from Ogundana et al. (2017) and IASB (2015).

Completeness refers to depiction of information, including descriptions and explanations that can be sufficient for decision-making (Ogundana et al., 2017; IASB, 2015). Completeness is measured using three-item scale modified from Ogundana et al. (2017) and IASB (2015).

Neutrality refers to the information without bias in the selection or presentation of financial data. Furthermore, neutral depiction is not slanted, weighted, emphasized, de-emphasized, or otherwise manipulated to increase the probability that it will be received favorably or unfavorably by users (Ogundana et al., 2017; Hasan et al., 2014). Neutrality is measured using three-item scale modified from Ogundana et al. (2017) and Yurisandi and Puspitasari (2015). 
Free from error refers to that there are no errors or omissions in the description of the phenomena and that the process used to produce the reported information has been selected and applied with no error in the process (Ogundana et al., 2017; IASB, 2015). Free from error is measured using three-item scale modified from Ogundana et al. (2017) and Yurisandi and Puspitasari (2015).

Verifiability refers to that accounting information can be measured, using the appropriate method which is based on GAAP, financial reporting standard. Moreover, knowledgeable and independent observers could reach consensus, but not necessarily complete agreement, that a depiction is a faithful representation (Socea, 2012; Berger, 2011). Verifiability is measured using three-item scale modified from Ogundana et al. (2017), Socea (2012), and Berger (2011).

Independent variable. For this research, independent variable is as an antecedent of financial reporting reliability. This variable is measured as an antecedent of financial reporting reliability including accountant professional ethics, AIS quality, audit committee effectiveness, and audit firm quality. The measurement of each antecedent variable conforms to relevant literature to be discussed as follows.

Accountant professional ethics is referred to as an accountant's behavior that corresponds with the professional code of ethics of IFAC in order to help predict competent outcome in a certain job that encompasses abilities, knowledge, skills, experience, and technology competency (Flood \& Wilson, 2008; Kennedy \& Dresser, 2005; Tontiset, 2018b). Accountant professional ethics is measured using three-item scale modified from Tontiset (2018b) and Flood and Wilson (2008).

AIS quality refers to the latency of accounting information system that provides building accounting information effectiveness. The characteristics of AIS quality are producing accurate data, timeliness, update, and effective link to other systems (Altamuro \& Beattey, 2010; Peppard \& Ward, 2004; O’Donnell \& David, 2000; Murthy \& Swanson, 1992). AIS quality is measured using four-item scale modified from Altamuro and Beattey (2010), Peppard and Ward (2004), and O’Donnell and David (2000).

Audit committee effectiveness refers to effective team of audit committee which is set and designed to prevent fraud in financial statement, prevent assets loss, and conduct its operation in an efficient and effective manner (Asiriuwa et al., 2018; Johnson et al., 2012; Jokipii, 2010; Altamuro \& Beatty, 2010). Asiriuwa et al. (2018) revealed that audit committee attributes include audit committee size, frequency of meetings, number of expertise, and overall effectiveness. Audit committee effectiveness is measured using three-item scale modified from Asiriuwa et al. (2018), Johnson et al. (2012), Jokipii (2010), and Altamuro and Beatty (2010).

Audit firm quality refers to Big 4 audit firms that are higher concentration of client's industry expertise, client experience, audit manager involvement, audit committee involvement, and skepticism (Asiriuwa et al., 2018; Tepalagul \& Lin, 2015; Samelson et al., 2006; Francis, 2004; Wooten, 2003; Behn et al., 1997; Sutton, 1993; Carcello et al., 1992). Audit firm quality is measured using three-item scale modified from Asiriuwa et al. (2018), Behn et al. (1997), and Carcello et al. (1992).

Two control variables are included to account for firm characteristics for the fact that they may influence the hypothesized relationships of both firm age and size. Firm age (FA) is measured by number of years that a firm has been in operation, and firm size (FS) is measured by total assets of the firm. Successful accounting information may be influenced by both firm age and size because it may be able to achieve high performance (Gotti \& Mastrolia, 2012; Tontiset, 2018a). 


\section{Reliability and Validity}

Factor analysis was firstly utilized to investigate the underlying relationships of a large number of items and to determine whether they can be reduced to a smaller set of factors. The factor analyses conducted were done separately on each set of the items representing a particular scale due to limited observations. With respect to the confirmatory factor analysis (CFA), this analysis has a high potential to inflate the component loadings based on a higher rule-of-thumb at a cut-off value of 0.40 (Hair, William, Barry, Rolph, \& Roanld, 2006). All factor loadings are greater than the 0.40 cut-off (0.74-0.95) and are statistically significant. The reliability of the measurements was evaluated by Cronbach alpha coefficients (0.69-0.92) which are greater than 0.70 (Hair et al., 2006). The scales of all measures appear to produce internally consistent results. Table 1 presents the results of both factor loadings and Cronbach alpha for multiple-item scales. Thus, this research expresses an accepted validity and reliability as shown in Table 1.

Table 1

Results of Factor Loadings and Cronbach Alpha Coefficients

\begin{tabular}{lll}
\hline Variables & Factor loadings & Cronbach alpha \\
\hline Predictive value $(P V)$ & $0.90-0.91$ & 0.77 \\
Confirmative value $(C V)$ & $0.76-0.91$ & 0.69 \\
Entity-specific material $(E M)$ & $0.74-0.80$ & 0.67 \\
Completeness $(C O)$ & $0.80-0.87$ & 0.70 \\
Neutrality ( $N E)$ & $0.89-0.92$ & 0.75 \\
Free from error $(F E)$ & $0.87-0.90$ & 0.78 \\
Verifiability (VE) & $0.84-0.95$ & 0.88 \\
Accountant professional ethics (APE) & $0.74-0.95$ & 0.85 \\
AIS quality (AISQ) & $0.89-0.95$ & 0.91 \\
Audit committee effectiveness (ACE) & $0.92-0.93$ & 0.92 \\
Audit firm quality (AFQ) & $0.86-0.94$ & 0.88 \\
\hline
\end{tabular}

\section{Statistic Test}

The Ordinary Least Squares (OLS) regression analysis is used to test all hypotheses of this research model. For this research, both dependent and independent variables are categorical and interval data. Thus, OLS is an appropriate method for examining the hypothesized relationships of this research model (Aulakh, Kotabe, \& Teegen, 2000). The relationship among independent, dependent, and control variables of this research model was initially assessed using regression analysis (Frazier, Barron, \& Tix, 2004). The models of the aforementioned relationships are shown as follows:

$$
\begin{gathered}
P V=\alpha_{1}+\beta_{1} A P E+\beta_{2} A I S Q+\beta_{3} A C E+\beta_{4} A F Q+\beta_{5} F S+\beta_{6} F A+\varepsilon \\
C V=\alpha_{2}+\beta_{7} A P E+\beta_{8} A I S Q+\beta_{9} A C E+\beta_{10} A F Q+\beta_{11} F S+\beta_{12} F A+\varepsilon \\
E M=\alpha_{3}+\beta_{13} A P E+\beta_{14} A I S Q+\beta_{15} A C E+\beta_{16} A F Q+\beta_{17} F S+\beta_{18} F A+\varepsilon \\
C O=\alpha_{4}+\beta_{19} A P E+\beta_{20} A I S Q+\beta_{21} A C E+\beta_{22} A F Q+\beta_{23} F S+\beta_{24} F A+\varepsilon \\
N E=\alpha_{5}+\beta_{25} A P E+\beta_{26} A I S Q+\beta_{27} A C E+\beta_{28} A F Q+\beta_{29} F S+\beta_{30} F A+\varepsilon \\
F E=\alpha_{6}+\beta_{31} A P E+\beta_{32} A I S Q+\beta_{33} A C E+\beta_{34} A F Q+\beta_{35} F S+\beta_{36} F A+\varepsilon \\
V E=\alpha_{7}+\beta_{37} A P E+\beta_{38} A I S Q+\beta_{39} A C E+\beta_{40} A F Q+\beta_{41} F S+\beta_{42} F A+\varepsilon
\end{gathered}
$$




\section{Results and Discussion}

The descriptive statistics and correlation matrix for all variables are shown in Table 2. Checking for significance of the relationships between each independent variable is tested by variance inflation factor (VIF) technique. The results show that VIFs range from 3.57 to 8.41, well below the cut-off value of 10 recommended by Neter, Wasserman, and Kutner (1985), indicating that the independent variables are not correlated with each other. Thus, there are no substantial multicollinearity problems encountered for this research.

Table 2

Descriptive Statistics and Correlation Matrix

\begin{tabular}{|c|c|c|c|c|c|c|c|c|c|c|c|c|c|}
\hline Variables & $P V$ & $C V$ & $E M$ & $\mathrm{CO}$ & $N E$ & $F E$ & $V E$ & $A P E$ & AISQ & $A C E$ & $A F Q$ & FS & $F A$ \\
\hline Mean & 4.45 & 4.40 & 4.36 & 4.41 & 4.46 & 4.46 & 4.65 & 4.54 & 4.32 & 4.46 & 4.41 & 2.45 & 2.27 \\
\hline SD & 0.53 & 0.62 & 0.61 & 0.58 & 0.56 & 0.55 & 0.49 & 0.49 & 0.58 & 0.62 & 0.60 & 0.94 & 1.14 \\
\hline VIF & & 8.24 & 7.21 & 8.41 & 6.45 & 4.90 & 7.60 & 6.70 & 7.40 & 5.79 & 6.58 & 7.29 & 3.57 \\
\hline \multicolumn{14}{|l|}{$P V$} \\
\hline$C V$ & $0.734^{* *}$ & & & & & & & & & & & & \\
\hline$E M$ & $0.668^{* *}$ & $0.661^{* *}$ & & & & & & & & & & & \\
\hline $\mathrm{CO}$ & $0.755^{* *}$ & $0.725^{* *}$ & $0.684^{* *}$ & & & & & & & & & & \\
\hline$N E$ & $0.734^{* *}$ & $0.789^{* *}$ & $0.683^{* *}$ & $0.922^{* *}$ & & & & & & & & & \\
\hline$F E$ & $0.574^{* *}$ & $0.669^{* *}$ & $0.595^{* *}$ & $0.607^{* *}$ & $0.651^{* *}$ & & & & & & & & \\
\hline$V E$ & $0.399^{* *}$ & $0.692^{* *}$ & $0.404^{* *}$ & $0.402^{* *}$ & $0.430^{* *}$ & $0.501^{* *}$ & & & & & & & \\
\hline$A P E$ & $0.501^{* *}$ & $0.494^{* *}$ & $0.448^{* *}$ & $0.422^{* *}$ & $0.318^{* *}$ & $0.498^{* *}$ & $0.367^{* *}$ & & & & & & \\
\hline AISQ & $0.327^{* *}$ & $0.333^{* *}$ & $0.354^{* *}$ & $0.156^{* *}$ & $0.136^{* *}$ & $0.496^{* *}$ & $0.341^{* *}$ & $0.641^{* *}$ & & & & & \\
\hline$A C E$ & $0.286^{* *}$ & $0.436^{* *}$ & $0.349^{* *}$ & $0.264^{* *}$ & $0.339^{* *}$ & $0.513^{* *}$ & $0.507^{* *}$ & $0.551^{* *}$ & $0.485^{* *}$ & & & & \\
\hline$A F Q$ & $0.267^{* *}$ & $0.389^{* *}$ & $0.408^{* *}$ & $0.350^{* *}$ & $0.294^{* *}$ & $0.428^{* *}$ & $0.140^{* *}$ & $0.428^{* *}$ & $0.374^{* *}$ & $0.451^{* *}$ & & & \\
\hline FS & $0.190^{*}$ & $0.188^{*}$ & 0.056 & 0.055 & 0.062 & 0.079 & 0.186 & 0.166 & $0.287^{* *}$ & $0.343^{* *}$ & 0.065 & 0.159 & \\
\hline$F A$ & 0.162 & 0.177 & 0.231 & 0.137 & $0.198^{*}$ & $0.204^{*}$ & $0.186^{*}$ & 0.053 & 0.125 & 0.111 & 0.144 & 0.191 & $0.222^{*}$ \\
\hline
\end{tabular}

Notes. : Correlation is significant at the 0.01 level (2-tailed); ${ }^{*}$ : Correlation is significant at the 0.05 level (2-tailed).

Table 3

Results of OLS Regression Analysis

\begin{tabular}{|c|c|c|c|c|c|c|c|}
\hline \multirow{3}{*}{ Independent variables } & \multicolumn{7}{|c|}{ Dependent variables } \\
\hline & $P V$ & $C V$ & $E M$ & $\mathrm{CO}$ & $N E$ & $F E$ & $V E$ \\
\hline & 1 & 2 & 3 & 4 & 5 & 6 & 7 \\
\hline \multirow[t]{2}{*}{ Accountant professional ethics (APE) } & $0.467^{* * *}$ & $0.326^{* * *}$ & $0.287^{*}$ & $0.470^{* * * *}$ & $0.270^{* *}$ & 0.148 & 0.088 \\
\hline & $(0.116)$ & $(0.111)$ & $(0.109)$ & $(0.115)$ & $(0.119)$ & $(0.098)$ & $(0.111)$ \\
\hline \multirow[t]{2}{*}{ AIS quality (AISQ) } & 0.018 & 0.052 & 0.129 & $0.201^{*}$ & 0.127 & $0.274^{* * *}$ & 0.090 \\
\hline & $(0.113)$ & $(0.107)$ & $(0.105)$ & $(0.111)$ & $(0.116)$ & $(0.095)$ & $(0.108)$ \\
\hline \multirow[t]{2}{*}{ Audit committee effectiveness (ACE) } & 0.010 & 0.170 & 0.040 & 0.038 & 0.146 & 0.138 & $0.447^{* * *}$ \\
\hline & $(0.108)$ & $(0.103)$ & $(0.101)$ & $(0.106)$ & $(0.110)$ & $(0.091)$ & $(0.103)$ \\
\hline \multirow[t]{2}{*}{ Audit firm quality ( $A F Q$ ) } & 0.059 & $0.203^{* *}$ & $0.306^{* * *}$ & $0.269^{* * *}$ & $0.203^{* *}$ & $0.300^{* * *}$ & 0.131 \\
\hline & $(0.096)$ & $(0.092)$ & $(0.090)$ & $(0.095)$ & $(0.098)$ & $(0.081)$ & $(0.092)$ \\
\hline \multirow[t]{2}{*}{ Firm size $(F S)$} & 0.095 & 0.192 & 0.101 & -0.025 & -0.195 & -0.114 & 0.280 \\
\hline & $(0.182)$ & $(0.173)$ & $(0.170)$ & $(0.180)$ & $(0.186)$ & $(0.153)$ & $(0.174)$ \\
\hline \multirow[t]{2}{*}{ Firm age $(F A)$} & -0.044 & 0.245 & $0.618^{* * *}$ & $0.366^{* *}$ & $0.388^{* *}$ & $0.539^{* * *}$ & $0.338^{* * *}$ \\
\hline & $(0.178)$ & $(0.170)$ & $(0.166)$ & $(0.176)$ & $(0.182)$ & $(0.150)$ & $(0.170)$ \\
\hline Adjusted $R^{2}$ & 0.217 & 0.325 & 0.317 & 0.236 & 0.179 & 0.446 & 0.288 \\
\hline
\end{tabular}

Notes. ${ }^{*}: p<0.10,{ }^{* * *}: p<0.05,{ }^{* * *}: p<0.01$. Beta coefficients with standard errors are in parenthesis. 
Table 3 presents the results of OLS regression analysis of the antecedents of financial reporting reliability (accountant professional ethics, AIS quality, audit committee effectiveness, and audit firm quality) on financial reporting reliability (predictive value, confirmative value, entity-specific material, completeness, neutrality, free from error, and verifiability) from H1a-g to H4a-g. The results show that accountant professional ethics has significant positive effects on dimensions of financial reporting reliability including predictive value (H1a, $b_{1}=0.467, p<0.01$ ), confirmative value (H1b, $b_{7}=0.326, p<0.01$ ), entity-specific material (H1c, $b_{13}=0.287$, $p<0.10$ ), completeness (H1d, $b_{19}=0.470, p<0.01$ ), and neutrality (H1e, $b_{25}=0.270, p<0.05$ ). However, the results show that accountant professional ethics has an insignificant effect on financial reporting reliability in dimensions of free from error (H1f, $b_{31}=0.148, p>0.05$ ) and verifiability (H1g, $b_{37}=0.088, p>0.05$ ). Overall, the results imply that accountant professional ethics is the primary of internal resource and capability variable that has an influence on producing financial reporting reliability (Enofe et al., 2015; Flood \& Wilson, 2008). Thus, Hypotheses 1a-e are supported while Hypotheses $1 \mathrm{f}$ and $1 \mathrm{~g}$ are not supported.

Moreover, Table 3 also shows the results of the OLS regression analysis of AIS quality on financial reporting reliability (predictive value, confirmative value, entity-specific material, completeness, neutrality, free from error, and verifiability) in Hypotheses 2a-g. The results show that AIS quality has significant positive effects on dimensions of financial reporting reliability including both completeness ( $\mathrm{H} 2 \mathrm{~d}, b_{20}=0.201, p<0.10$ ) and free from error (H2f, $b_{32}=0.274, p<0.01$ ). However, the results show that AIS quality has an insignificant effect on financial reporting reliability in dimensions of predictive value (H2a, $b_{2}=0.018, p>0.05$ ), confirmative value ( $\mathrm{H} 2 \mathrm{~b}, b_{8}=0.052, p>0.05$ ), entity-specific material (H2c, $b_{14}=0.129, p>0.05$ ), neutrality (H2e, $b_{26}=0.127, p>0.05$ ), and verifiability (H2g, $b_{38}=0.090, p>0.05$ ). Overall, the results imply that AIS quality has an influence on building financial reporting reliability (Abdullah et al., 2015; Altamuro \& Beattey, 2010; Peppard \& Ward, 2004; O’Donnell \& David, 2000). Thus, Hypotheses 2d and 2f are supported while Hypotheses 2a, 2b, 2c, 2e, and 2g are not supported.

Furthermore, Table 3 also shows the results of OLS regression analysis of audit committee effectiveness on financial reporting reliability (predictive value, confirmative value, entity-specific material, completeness, neutrality, free from error, and verifiability) in Hypotheses 3a-g. The results show that audit committee effectiveness has significant positive effects on financial reporting reliability in only dimension of verifiability (H3g, $b_{39}=0.447, p<0.01$ ). However, the results show that audit committee effectiveness has an insignificant effect on financial reporting reliability in dimensions of predictive value (H3a, $b_{3}=0.010, p>0.05$ ), confirmative value (H3b, $b_{9}=0.170, p>0.05$ ), entity-specific material ( $\mathrm{H} 3 \mathrm{c}, b_{15}=0.040, p>0.05$ ), completeness (H3d, $b_{21}=0.038, p>0.05$ ), neutrality (H3e, $b_{27}=0.146, p>0.05$ ), and free from error (H3f, $b_{33}=0.138, p>0.05$ ). Overall, the results imply that audit committee effectiveness has an influence on creating financial reporting reliability in only dimension of verifiability (Yurisandi \& Puspitasari, 2015; Hasan et al., 2014; Klai, 2011; Schneider et al., 2009; Ashbaugh-Skaife et al., 2007). Thus, only Hypothesis 3g is supported while Hypotheses 3a, 3b, 3c, 3d, 3e, and 3f are not supported.

Finally, Table 3 also shows the results of OLS regression analysis of audit firm quality on financial reporting reliability (predictive value, confirmative value, entity-specific material, completeness, neutrality, free from error, and verifiability) in Hypotheses 4a-g. The results show that audit firm quality has significant positive effects on dimensions of financial reporting reliability in dimensions of confirmative value (H4b, $b_{10}=0.203, p<0.05$ ), entity-specific material (H4c, $b_{16}=0.306, p<0.01$ ), completeness (H4d, $b_{22}=0.269$, $p<0.01$ ), neutrality (H4e, $b_{28}=0.203, p<0.05$ ), and free from error (H4f, $b_{34}=0.300, p<0.01$ ). However, the 
results show that audit firm quality has an insignificant effect on financial reporting reliability in dimensions of both predictive value ( $\mathrm{H} 4 \mathrm{a}, b_{4}=0.059, p>0.05$ ) and verifiability ( $\left.\mathrm{H} 4 \mathrm{~g}, b_{40}=0.131, p>0.05\right)$. Overall, the results imply that audit firm quality has an influence on enhancing financial reporting reliability (Asiriuwa et al., 2018; Tepalagul \& Lin, 2015; Adeyemi, Okpala, \& Dabor, 2012; Behn et al., 1997; Carcello et al., 1992). Thus, Hypotheses 4b, 4c, 4d, 4e, and 4f are supported while Hypotheses 4a and 4g are not supported.

\section{Theoretical Implications}

\section{Implication of Research}

This research provides an important extension on previous knowledge and relevant literature of financial reporting reliability. Moreover, this research focuses on the key dimensions of financial reporting reliability including predictive value, confirmative value, entity-specific material, completeness, neutrality, free from error, and verifiability. Furthermore, this research focuses on internal resources and capabilities including accounting professional ethics, AIS quality, and audit committee effectiveness which can be explained by RBV of the firm. The results indicate that accounting professional ethics, AIS quality, and audit committee effectiveness have a significant effect on financial reporting reliability. Moreover, audit firm quality is also significantly related with financial reporting reliability. The result implies that internal resources and capabilities of the firm can enhance financial reporting reliability. Corresponding with the stakeholder theory, the results imply that company must provide big audit firm in order to give financial reporting user confidence.

\section{Managerial Implications}

This research helps chief accounting officers, accounting controllers, bookkeepers, and financial reporting users identify and justify the key components of financial reporting reliability. Chief accounting officers and bookkeepers should effectively manage and produce reliable financial reporting for users. Chief accounting officers should implement AIS quality and audit committee effectiveness, improve effective accountant professional ethics, and bring larger audit firm in order to build reliable financial reporting in the long term.

\section{Limitation and Suggestion for Future Research}

According to the results, constructs of this research are developed and measured by using only previous research. Thus, future research should explore the scale by different approaches, such as in-depth interview or focus group, in order to fully understand constructs measurement. Moreover, this research uses only questionnaires for collecting data. Since then, future research may be developing longitudinal data and/or mixed methods designed to observe the research model. Finally, the results of this research are derived from the listed companies in the SET. Furthermore, future research may be collecting data from another population in order to widen the perspective and generalization.

\section{Conclusion}

Nowadays, the topic of financial reporting reliability is very important for accounting practitioners. Based on financial accounting research, we found both insufficiency of financial reporting reliability measurement and ambiguity about the antecedents of financial reporting reliability. Thus, this research attempts to identify financial reporting reliability and investigate its antecedents. This research proposes a research model and hypotheses that build on RBV of the firm, stakeholder theory, and relevant literature of financial reporting reliability. Thai-listed companies were selected as a sample and data are collected from chief accountant officer by using a questionnaire as an instrument. Finally, 119 mail questionnaires were usable. 
Overall, the result shows that accountant professional ethics, AIS quality, audit committee effectiveness, and audit firm quality have a positive significant effect on financial reporting reliability including predictive value, confirmative value, entity-specific material, completeness, neutrality, free from error, and verifiability. This research also provides both theoretical and managerial contributions to expanding on previous literature of financial reporting reliability and suggests a critical point for financial accounting researchers and accounting professionals.

\section{References}

Abdullah, Z. I., Almsafir, M. K., \& Al-Smadi, A. A. (2015). Transparency and reliability in financial statement: Do they exist? Evidence form Malaysia. Open Journal of Accounting, 4(4), 29-43.

Adediran, S. A., Alade, S. O., \& Oshode, A. A. (2013). Reliability of financial reporting and companies attribute: The Nigerian experience. Research Journal of Finance and Accounting, 4(16), 108-114.

Adeyemi, S. B., Okpala, O., \& Dabor, E. L. (2012). Factors affecting audit quality in Nigeria. International Journal of Business and Social Science, 3(20), 198-209.

Altamuro, J., \& Beattey, A. (2010). How does internal control regulation affect financial reporting? Journal of Accounting and Economics, 49(1-2), 58-74.

Ashbaugh-Skaife, H., Collins, D., \& Kinney, W. (2007). The discovery and reporting of internal control deficiencies prior to SOX-mandated audits. Journal of Accounting and Economics, 44(1-2), 166-192.

Asiriuwa, O., Aronmwan, E. J., Uwuigbe, U., \& Uwuigbe, O. R. (2018). Audit committee attributes and audit quality: A benchmark analysis. Business: Theory and Practice, 19(7), 37-48.

Aulakh, P. S., Kotabe, M., \& Teegen, H. (2000). Export strategies and performance of firms from emerging economies: Evidence from Brazil, Chile, and Mexico. Academy of Management Journal, 43(3), 342-361.

Baker, C. R., \& Barbu, E. M. (2007). Trends in research on international accounting harmonization. The International Journal of Accounting, 42(3), 272-304.

Barney, J. (1991). Firm resources and sustained competitive advantage. Journal of Management, 17(1), 99-120.

Beaver, W. H. (1998). Financial reporting: An accounting revolution (3rd ed.). Upper Saddle River, NJ: Prentice Hall.

Behn, B. K., Carcello, J. V., Hermanson, D. R., \& Hermanson, R. H. (1997). The determinants of audit client satisfaction among clients of big 6 firms. Accounting Horizons, 11(1), 7-24.

Berger, P. G. (2011). Challenges and opportunities in disclosure research-A discussion of the financial reporting environment: Review of the recent literature. Journal of Accounting and Economics, 51(1), 204-218.

Beyer, A., Cohen, D. A., Lys, T. Z., \& Walther, B. R. (2010). The financial reporting environment: Review of the recent literature. Journal of Accounting and Economics, 50(2-3), 296-343.

Biddle, G. C., Hilary, G., \& Verdi, R. S. (2009). How does financial reporting quality related to investment efficiency. Journal of Accounting and Economics, 48(2-3), 112-131.

Cadez, S., \& Guilding, C. (2008). An exploratory investigation of an integrated contingency model of strategic management accounting. Accounting, Organizations and Society, 33(7-8), 836-863.

Carcello, J. V., Hermanson, R. H., \& McGrath, N. T. (1992). Audit quality attributes: The perceptions of audit partner, preparers, and financial statement users. Auditing: A Journal of Practice and Theory, 11(1), 1-15.

Cheng, C. S. A., Ferris, K. S., Hsieh, S., \& Su, Y. (2005). The value relevance of earnings and book value under pooling and purchase accounting. Advances in Accounting, 21, 25-59.

Churchill, G. A. J. (1979). A paradigm for developing better measure of marketing constructs. Journal of Marketing Research, 16(1), 64-73.

Cohen, J., Krishnamoorthy, G., \& Wright, A. (2004). The corporate governance mosaic and financial reporting quality. Journal of Accounting Literature, 23(1), 1-80.

Enofe, A. O., Ukpebor, I., \& Ogbomo, N. (2015). The effect of accounting ethics in improving auditor professional skepticism. International Journal of Advanced Academic Research, 1(2), 1-16.

Flood, B., \& Wilson, R. M. S. (2008). An exploration of the learning approaches of prospective professional accountants in Ireland. Accounting Forum, 32(3), 225-239.

Francis, J. R. (2004). What do we know about quality? The British Accounting Review, 36(4), 345-368. 
Frazier, P. A., Barron, K. E., \& Tix, A. P. (2004). Testing moderator and mediator effects in counseling psychology. Journal of Counseling Psychology, 51(1), 115-134.

Gotti, G., \& Mastrolia, S. (2012). The effect on financial reporting quality of an exemption from the SEC reporting requirements for foreign private issuers. The International Journal of Accounting, 47(1), 44-71.

Hair, J. F., William, B. C., Barry, B. J., Rolph, A. E., \& Roanld, T. L. (2006). Multivariate data analysis. New York, NY: Pearson Education International.

Hasan, M. S., Abdullah, S. N. B., \& Hossain, S. Z. (2014). Qualitative characteristics of financial reporting. The Pakistan Accountant, 23-31.

Henri, J. F. (2006). Management control systems and strategy: A resource-based perspective. Accounting, Organizations and Society, 31(6), 529-558.

International Accounting Standards Board [IASB]. (2010). A framework-based approach to teaching accounting: Property, plant, and equipment. Retrieved from http://www.ifrs.org/Documents/BodrumHandout.pdf

International Accounting Standards Board [IASB]. (2015). Conceptual framework for financial reporting. Retrieved from http://www.ifrs.org

International Federation of Accountants [IFAC]. (2012). Conceptual framework for general purpose financial reporting by public sector entities: Presentation in general purpose reports. Retrieved from https://www.ifac.org/system/files/publications/files/CP_Conceptual_Framework_for_G_P_Financial_Reporting.pdf

Johnson, L. E., Lowensohn, S., \& Reck, J. L. (2012). Management letter comments: Their determinants and their association with financial reporting quality in local government. Journal of Accounting Public and Policy, 31(6), 575-592.

Jokipii, A. (2010). Determinants and consequences of internal control in firms: A contingency theory based analysis. The Journal of Management and Governance, 14(2), 115-144.

Kamolsakulchai, M. (2015). The impact of the audit committee effectiveness and audit quality on financial reporting quality of listed company in the Stock Exchanges of Thailand. Review of Integrative Business \& Economic, 4(2), 328-341.

Kennedy, P. W., \& Dresser, S. G. (2005). Creating a competency-based workplace. Benefits and Compensation Digest, 42(2), 20-23.

Klai, N. (2011). Corporate governance and financial reporting quality. International Business Research, 4(1), 158-166.

Kusnadi, Y., Leong, K. S., Suwardy, T., \& Wang, J. (2015). Audit committees and financial reporting quality in Singapore. Journal of Business Ethics, 139(1), 1-48.

Lehman, G. (1999). Disclosing new world: A role for social and environmental accounting and auditing. Accounting, Organizations and Society, 24(3), 217-241.

Li, F., \& Shroff, N. O. (2014). Financial reporting quality and economic growth. Retrieved from http://papers.ssrn.com/sol3/papers.cfm?abstract_id=1265331

Ma, J., \& Ma, C. (2011). Factor analysis based on the COSO framework and the government audit performance of control theory. Procedia Engineering, 15, 5584-5589.

Mahadeo, J. D., Oogarah-Hanuman, V., \& Soobaroyen, T. (2011). Change in social and environmental reporting practices in an emerging economy (2004-2007): Exploring the relevance of stakeholder and legitimacy theories. Accounting Forum, 35(3), 158-175.

Maines, L. A., \& Wahlen, J. M. (2006). The nature of accounting information reliability: Inferences from archival and experimental research. Accounting Horizons, 20(4), 399-425.

Marriner, S. N., \& Nuseiben, T. N. (2004). Quality of financial reporting: Evidenced from the listed Saudi nonfinancial companies. The International Journal of Accounting, 21(2), 461-491.

Mbobo, M. E., \& Ekpo, N. B. (2016). Operationalising the qualitative characteristics of financial reporting. International Journal of Finance and Accounting, 5(4), 184-192.

McCartney, S. (2004). The use of usefulness: An examination of the use needs approach to the financial reporting conceptual framework. The Journal of Applied Accounting Research, 7(2), 52-79.

Meek, G. K., \& Thomas, W. B. (2004). A review of market-based international accounting research. Journal of International Accounting Research, 3(1), 21-41.

Moeller, R. R. (2011). COSO enterprise risk management: Establishing effective governance, risk, and compliance process. Hoboken, New Jersey: John Wiley \& Sons, Inc.

Murthy, U. S., \& Swanson, J. A. (1992). Integrating expert systems and database technologies: An intelligent decision support system for investigating cost variances. Journal of Information Systems, 6(2), 127-148. 
Naser, K., \& Nuseibeh, R. (2003). Quality of financial reporting: Evidence from the listed Saudi nonfinancial companies. The International Journal of Accounting, 38(1), 41-69.

Neter, J., Wasserman, W., \& Kutner, M. H. (1985). Applied linear statistical models: Regression, analysis of variance, and experimental design (2nd ed.). Homewood: Richard D. Irwin, Inc.

O’Donnell, E., \& David, J. S. (2000). How information systems influence user decisions: A research framework and literature review. International Journal of Accounting Information Systems, 1(3), 178-203.

Ogundana, O., Ojeka, S., Ojua, M., \& Nwaze, C. (2017). Quality of accounting information and information and internal audit characteristic in Nigeria. Journal of Modern Accounting and Auditing, 13(8), 333-344.

Pavabutr, P., \& Prangwattananon, S. (2009). Tick size change on the Stock Exchange of Thailand. Review of Quantitative Finance and Accounting, 32(4), 351-371.

Peppard, J., \& Ward, J. (2004). Beyond strategic information systems: Towards an IS capability. The Journal of Strategic Information Systems, 13(2), 167-194.

Russo, M. V., \& Fouts, P. A. (1997). A resource-based perspective on corporate environmental performance and profitability. Academy Management Journal, 40(3), 534-539.

Samelson, D., Lowensohn, S., \& Johnson, L. E. (2006). The determinants of perceived audit quality and audittee satisfaction in local government. Journal of Public Budgeting, Accounting \& Financial Management, 18(2), 139-166.

Schneider, A., Gramling, A. A., Hermanson, D. R., \& Ye, Z. (2009). A review of academic literature on internal control reporting under SOX. Journal of Accounting Literature, 28, 1-46.

Shahwan, Y. (2008). Qualitative characteristics of financial reporting: A historical perspective. Journal of Applied Accounting Research, 9(3), 192-202.

Socea, A. D. (2012). Managerial decision-making and financial accounting information. Procedia-Social and Behavioral Sciences, 58, 47-55.

Spatacean, I. (2012). Addressing fraud risk by testing the effectiveness of internal control over financial feporting-Case of Romanian financial investment companies. Precedia Economics and Finance, 3(9), 230-235.

Suttipun, M. (2018). The influence of corporate governance, and sufficiency economy philosophy disclosure on corporate financial performance: Evidence from Thailand. Asia-Pacific Journal of Business Administration, 10(1), 79-99.

Sutton, S. G. (1993). Toward an understanding of the factors affecting the quality of the audit process. Decision Sciences, 24(1), 88-105.

Tepalagul, N., \& Lin, L. (2015). Auditor independence and audit quality: A literature review. Journal of Accounting, Auditing \& Finance, 30(1), 101-121.

Tontiset, N. (2018a). Analysis of the factors affecting successful accounting information of listed companies in the Stock Exchange of Thailand. Journal of Modern Accounting and Auditing, 14(3), 103-112.

Tontiset, N. (2018b). The effect of executive management support and cost accountant competency on CMS design effectiveness and its consequence: An empirical research of manufacturing business in Thailand. Journal of Modern Accounting and Auditing, 14(2), 1-9.

Tontiset, N., \& Ittarat, P. (2014). The effect of audit quality and service quality on client satisfaction and client loyalty: An empirical research of Thai-listed companies. International Journal of Business Strategy, 14(2), 105-116.

Tontiset, N., \& Kaiwinit, S. (2015). Internal control system effectiveness of Thai-listed companies: An empirical research of its antecedents and consequences. Review of Business Research, 15(1), 95-110.

Watts, R. L., \& Zimmerman, J. L. (1986). Positive accounting theory. Upper Saddle River, NJ: Printice Hall.

Wooten, T. C. (2003). Research about audit quality. The CPA Journal, 73(1), 48-51.

Yurisandi, T., \& Puspitasari, E. (2015). Financial reporting quality-Before and after IFRS adoption using NiCE qualitative characteristics measurement. Procedia-Social Behavioral Sciences, 211, 644-652. 